NBER WORKING PAPER SERIES

\title{
THE LOCATION OF OVERSEAS PRODUCTION AND PRODUCTION FOR EXPORT BY U.S. MULTINATIONAL FIRMS
}

Irving B. Kravis

Robert E. Lipsey

Working Paper No. 482

\author{
NATIONAL BUREAU OF ECONOMIC RESEARCH \\ 1050 Massachusetts Avenue \\ Cambridge MA 02138 \\ June 1980
}

The research reported here is part of the NBER's research program in International Studies. Any opinions expressed are those of the authors and not those of the National Bureau of Economic Research. 


\author{
The Location of Overseas Production and \\ Production for Export by U.S. Multinational Firms
}

\begin{abstract}
The location of overseas manufacturing production by U.S. firms seems to have been strongly influenced by common factors that operate in all industries: notably proximity to the United States and to other markets. Within industries, the choices made by parent firms among locations appear to show a tendency of "opposites attract," with low-wage and low-capital-intensity parents choosing high-wage, high-capital-intensity countries and high-wage, high-capital-intensity parents making the opposite choice.

Production for export seems to have been most strongly attracted by large internal markets in host countries. Economies of ocale in production presumably made large markets also economical as export bases. Another factor was high trade propensities oi host countries, which we interpret as representing access to imported materials at low world prices or better transport, finance, and other trade facilities.

Labor cost seems to have been a weak influence on location cholces. U.S. firms tended to export from high-wage countries but the high productivity in such countries more than offset the high wages. However, labor cost, to the extent we could measure $1 t$, was not in general a major influence on the location of export production.
\end{abstract}

Dr. Irving B. Kravis Department of Economics 368 McNe1l Butlding University of Pennsylvania Philadelphia, Pennsyl vania (215) 243-5692
Dr. Robert E. Lipsey

National Bureau of Economlc Research 15-19 West 4th Street, 8th Floor New York, New York 10012 (212) 598-3533 
The Location of Overseas Production and

Production for Export by U.S. Multinational Firms

Irving B. Rravis*

Robert E. Lipsey **

Introduction

Our purpose in this study has been to contribute to an understanding

of the way in which the behavior of multinational firms affects the

location of the world's manufacturing production. ${ }^{1}$ We discuss here one

part of that story: the determinants of U.S. firms' decisions about the

location of their own activities.

*National Bureau of Economlc Research and University of Pennsylvania.

**

National Bureau of Economic Research and Queens College, City University of New York.

1

This paper was prepared for presentation at a Ford Foundation Conference on Empirical Trade Policy Analysis at the University of Western Ontar1o, May 3-5, 1980. The work reported on here, which 18 part of the NBER's program in International Studies, was performed mainly under a grant to the National Bureau from the Ford Foundation and was alded also by a contract with the U.S. Department of Labor and the Treas ury Department. We also draw on some preliminary results of a National Bureau study supported by the National Science Foundation on Multinational Firms and Host-Country Technology, and a study of multinational firms' adaptation to factor prices that was part of Anne Krueger's project on Trade Policy and Employment in Less Developed Countries, financed by the Agency for International Development. We are grateful to these agencies for their support and also to the City University of New York for grants of computer time. Most of the data are those of the Bureau of Economic Analysis, U.S. Department of Commerce, and we are most appreciative of the assistance of Arnold Gilbert of that agency who supervised the calculat1ons.

The views represented here are those of the authors and do not necessarily represent those of the funding agencies. This is not an official National Bureau report; in particular it has not been submitted to the Board of Directors for approval. 
Two opposing hypotheses about the essential character of U.S. multinational firms have been offered to explain their decision making with respect to the location of production. One, the market scanning hypothesis, holds that multinationals use their superior knowledge to locate manufacturing activities in countries that are most advantageous from the standpoint of market opportunities and cost considerations. The other hypothesis views multinationals as market makers; multinationals are regarded as suffictently sheltered from competition and consequently so powerful and profitable that their strategies for dealing with the tax and other impacts upon them of host governments tend to subordinate the economic factors that ordinarily affect the location of industries, particularly cost considerations.

We attempt in this paper to see how far we can explain these location decisions by the economic considerations implied by the scanning hypothesis. The view of multinational firms we adopt for this purpose is that production in a host country is the result of the interaction of several sets of factors. Two of these are the standard trade-theory influences which involve the interaction of country characteristics (such as factor abundance and factor prices) and commodity characteristics (such as factor intensities). These are elements that are described by Dunning, for example, as external to the firm. ${ }^{2}$ They explain the desirability, in terms of

\section{2} Dunning (1977). 
cost, of producing a particular commodity in a particular country. The other set of factors consists of firm characteristics, which Dumning (ibid) refers to as internal to the firm, and which determine the ownership of production. They are what enable a multinational to produce in a host country in competition with host-country firms that presumably have the advantage of being on their home ground. These internal characteristics can themselves be broken down into several elements: those belonging to the home countries of the multinationals, those belonging to particular industries, and finally those specific to individual firms that differentiate them even from other firms in their own countries and industries. Home-country characteristics would be those that would be typical, say, of firms from the United States as compared to those from other countries, such as skill at mass-marketing. These would have to be attributes that become internal to the firm and are then carried over to production in other countries. Industry characteristics would be those common to firms in an industry regardless of their national origin, such as, perhaps, a high degree of product differentiation in the machinery industry.

If industry characteristics are dominant, we might expect to find that the same industries are foreign investors from each country, and that the propensities of companies to invest abroad would be determined by their industries but not by their national origins. If country characteristics were important, the industries investing heavily abroad from the United States would be those in which U.S. companies had developed special advantages (such as skill at mass-marketing or petroleum exploration) while the Swedish industries investing abroad might be quite a 
different group. ${ }^{3}$ Since the advantages of firms are in comparison to the characteristics of firms in other countries, the composition of investment w111 differ by area. U.S. firms might have a strong advantage in R\&D-intensive activities relative to host-country firms in LDC's, but much less of an advantage relative to host-country firms in Western Europe. Thus the composition of investment will differ not only among parent countries but among host countries, and the advantages of host-country firms as we 11 as those of parent-country firms should explain the pattern of Investment.

Within each industry in à parent country firms may vary over a wide range in the characteristics that determine firm-specific comparative advantage. Even in an R\&D-intensive industry there w111 be companies that lead in $R \& D$ investment or in innovation and others that are mainly followers or copiers. Thus we may find that even in a single industry within a single parent country, firms with different characteristics will have very different propensities to produce abroad or to produce in particular countries. The company attribute that has most frequently been Identified as determining the propensity to produce outside the home country is size, with a study by Horst (1972) as the main evidence. However, even the relation to size is complex. While the likelihood that a firm will be a forelgn investor or a forelgn investor in several countries does increase with size of $\mathrm{flrm}$, among investors, the propensity to produce abroad--the proportion of production or employment that takes place overseas--does not seem to be related to the size of the firm. Thus the

3

For a discussion of country differences see Swedenborg (1979), Chapter 3. The contrary view, that all multinational firms, whatever their national origin, "...have the same repertoire of advantages...." is taken by Samuelsson (1977), p. 185. 
influence of size seems to be mainly a threshhold effect. 4

In this paper we take up two issues related to the location decisions of U.S. multinational firms. One is whether, within industries, firm attributes are associated with the location of investments. The second is whether across all industries there are country attributes which determine the location of production for exports. We have not investigaged the industry attributes which may determine these decisions or the interaction among firm, industry, and country characteristics.

See Swedenborg (1979) for the relation among Swedish investors. The same seems to be the case for U.S. Investing firms. 
Who Invests Where? Parent Firm Characteristics and

the Location of Foreign Production

One way in which the location of production is determined is that parent firms that have decided to manufacture abroad select a location or locations for these operations. It has been suggested that this is a separate decision from later ones about the magnitude and character of the individual operations, 5 and we wish to ask, therefore, whether there is some relation between the characteristics of a country and the type of firm that sets up manufacturing there.

Table 1 shows, for a detailed country breakdown but a rough one for industries, that we may have a difficult time explaining these decisions as the result of an interaction between country and parent characteristics. Although there are differences in the ranking of countries in the six industries listed, what is much more striking is the consistency of the country ranking from one industry to another. Canada invariably ranks first in the number of U.S. parents operating there, the U.K. and Mexico alternate for second and third place, Germany and France, followed by Australia have most of the fourth, fifth, and sixth places, Sweden, Switzerland, and the Philippines share most of the last few ranks.

The rankings for a few countries, with a finer level of industry detail, are given in Table 2. Again, Canada is almost always first, followed by the U.K., Germany, and Sweden in that order.

The point of these tables is not that there is no interaction of the sort hypothesized, but that country characteristics by themselves seem to dominate these decisions. Proximity to the United States would seem to be the most important consideration, to judge by the high rank 
Table 1

Number of U.S. Parent Firms in Each Manufacturing Industry Group Active in Each Country or Group of Countries - 1966

\begin{tabular}{|c|c|c|c|c|c|c|}
\hline & $\begin{array}{c}\text { Food } \\
\text { Products }\end{array}$ & $\begin{array}{l}\text { Chemical } \\
\text { Products }\end{array}$ & $\begin{array}{c}\text { Primary } 8 \\
\text { Fabricated } \\
\text { Metals }\end{array}$ & Machinery & $\begin{array}{l}\text { Transport } \\
\text { Equipment }\end{array}$ & $\begin{array}{l}\text { Other } \\
\text { Mfg. }\end{array}$ \\
\hline A11 Countries & 172 & 341 & 316 & 595 & 129 & 729 \\
\hline Developed Countries & 116 & 295 & 276 & 547 & 117 & 616 \\
\hline Canada & 77 & 201 & 180 & 331 & 83 & 418 \\
\hline Europe & 73 & 219 & 148 & 380 & 56 & 376 \\
\hline UK & 39 & 124 & 70 & 213 & 23 & 201 \\
\hline Ge rmany & 28 & 73 & 48 & 107 & 17 & 105 \\
\hline Belgium-Luxembourg & 15 & 52 & 25 & 53 & 7 & 50 \\
\hline France & 24 & 91 & 27 & 90 & 20 & 100 \\
\hline Italy & 20 & 63 & 20 & 71 & 10 & 63 \\
\hline Netherlands & 18 & 53 & 28 & 49 & 7 & 57 \\
\hline Spain & 19 & 40 & 10 & 26 & 10 & 34 \\
\hline Sweden & 3 & 18 & 8 & 14 & 1 & 19 \\
\hline Switzerland & 4 & 32 & 7 & 20 & 4 & 30 \\
\hline Japan & 15 & 53 & 17 & 60 & 10 & 47 \\
\hline Australia & 23 & 77 & 27 & 72 & 15 & 83 \\
\hline South Africa & 12 & 43 & 16 & 30 & 11 & 38 \\
\hline Developing Countries & 106 & 191 & 107 & 193 & 50 & 286 \\
\hline Latin America & 93 & 170 & 91 & 163 & 48 & 224 \\
\hline Argentina & 18 & 57 & 18 & 36 & 17 & 34 \\
\hline Brazil & 16 & 63 & 21 & 58 & 15 & 49 \\
\hline Colombia & 16 & 44 & 14 & 18 & 3 & 35 \\
\hline Mexico & 46 & 120 & 72 & 112 & 34 & 137 \\
\hline Venezuela & 26 & 53 & 11 & 17 & 10 & 46 \\
\hline India & 3 & 33 & 15 & 29 & 5 & 21 \\
\hline Philippines & 23 & 27 & 6 & 12 & 1 & 36 \\
\hline
\end{tabular}

Source: U.S. Department of Commerce (1976). 
Table 2

Ranking a of Four Countries by Number of U.S. Parent F1rms in Each Industry - 1970

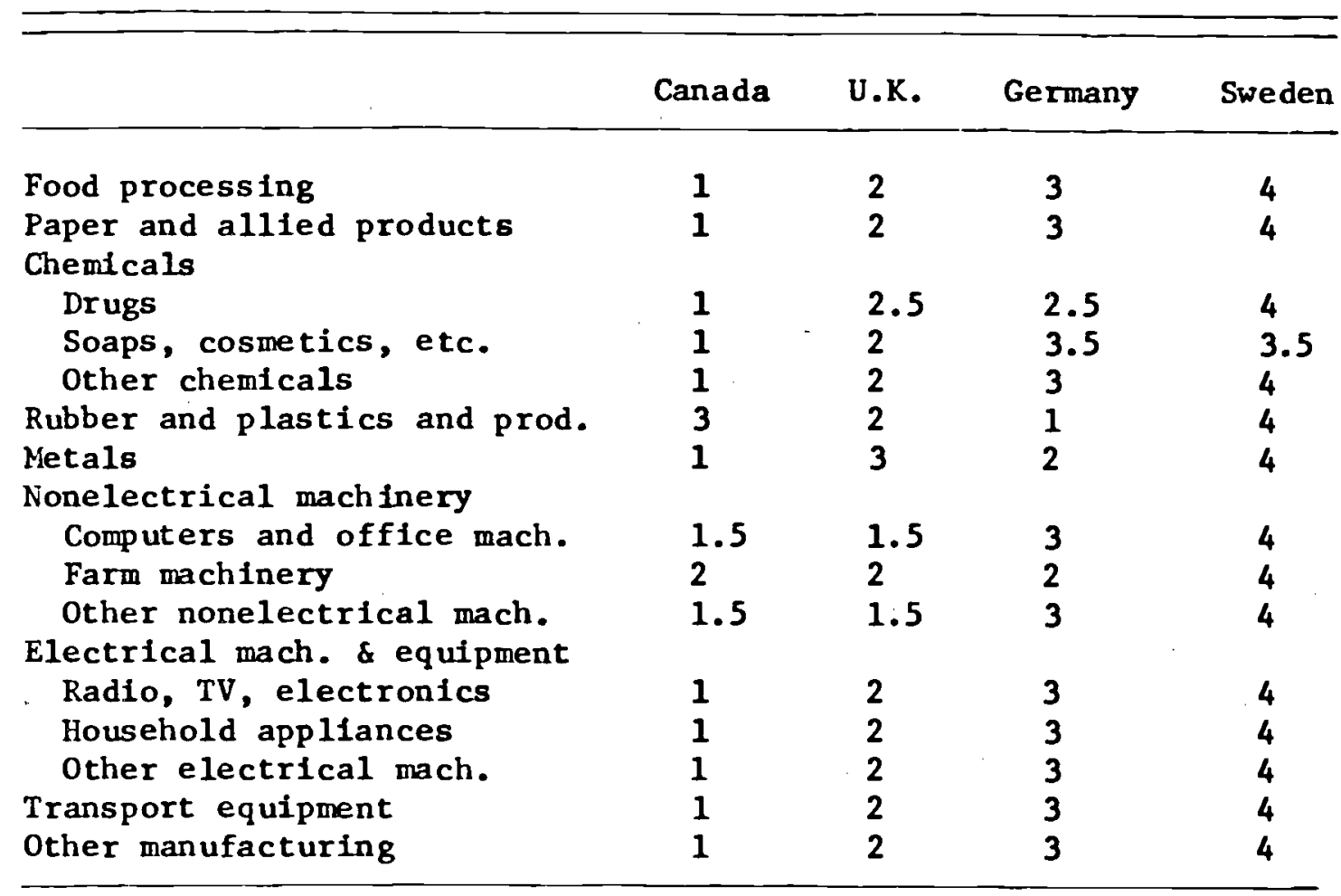

Source: U.S. Department of Commerce, unpublished data.

a From high (1) to low (4). 
of two such different countries as Canada and Mexico. The use of English as the major language seems also to be a factor, contributing probably to the rankings of Canada, the U.K., and Australia. The size of markets also appears to be a factor that would explain some of the rankings, and will be discussed more fully later.

A possible interpretation of the figures is that there is a regular country order in the establishment of affiliates and that it is mostly Identical among industries. The country order does not necessarily imply a timing relationship, although there very likely is one. The country order might simply be that if a company has an affiliate in only one country the affiliate will be in Canada. If it has two, they will be in Canada and In Mexico or the U.K., If it has more than three, they will be in those three countries and Germany or France, or possibly Australia. If there is a timing relationship it would be that U.S. companies establish affiliates first in Canada and last in Sweden or the Philippines, among the countries we have distinguished. Another possibility is that the country order is associated with the size of the parent. That 1s, the smallest parents have affiliates only in Canada and only the largest have affiliates in the low-ranking countries.

The last possibility is tested in Table 3 in which we rank the countries of Table 2 by the average number of employees in parent operations in the United States for parents in each Industry of manufacturing affiliates in that country. As we might expect, parents of Canadian affiliates are the smallest, in general and in most industries. In every industry for which we have data, parents of Swedish affiliates are the largest companies. The other two countries sometimes exchange ranks, and their 
Table 3

Ranking of Four Countries by Average Size (Employment) of U.S. Parents in Each Industry Manufacturing There - 1970

\begin{tabular}{lcccc}
\hline & Canada & U.K. & Germany & Sweden \\
\hline Food processing & 2 & 3 & 4 & 1 \\
Paper and allied products & 3 & 4 & 2 & 1 \\
Chemicals & 4 & 2 & 3 & 1 \\
Rubber and plastics and prod. & 1 & 3 & 2 & NA \\
Metals & 4 & 2 & 3 & 1 \\
Nonelectrical machinery & 4 & 2 & 3 & 1 \\
Electrical machinery & 4 & 3 & 2 & 1 \\
Transport equipment & 3 & 2 & 1 & NA \\
Other manufacturing & 3 & 2 & 1 & 1 \\
$\quad$ Average & 3.1 & 2.6 & 2.3 & 1 \\
\hline Average (six industries) & 3.5 & 2.7 & 3.0 & \\
\hline
\end{tabular}

Source: U.S. Department of Comnerce, umpublished data.

a

From high (1) to low (4).

b

Industries for which Swedish data are avallable. 
average ranks are simflar. Thus it appears that there is a size-ofparent order to the establishment of affiliates in general, across Industries, with affiliates in the less popular countries established mainly by firms which already have affiliates in the more popular countries. 6

Aside from size of parent, there may be other characteristics that distinguish parents locating their production in different countries. For example, labor-intensive U.S. firms might go abroad to countries where labor is cheap, or low-wage (presumably low-skili) U.S. companies might tend to have affiliates in low-wage countries abroad. We make a first test of such within-industry selection, using our broad country groupings, In Table 4, which shows the average rank for each country or country group, across industries, for the characteristics of U.S. parents and their affiliates.

The data suggest some consistency in parent rankings from one industry to another, but in surprising directions. The lowest-wage U.S. companies (or lowest-skill) tended to be the parents of affiliates in Canada and Sweden, two very high-wage countries. The highest-wage U.S. parents were more 1ikely to be the ones with affillates In "Other Europe," a comparatively low-wage area, although it contains a wide variety of countries, and with affiliates in Developing Countries. Thus, within each industry, parents seem to have selected foreign locations with characteristics least like their own. In other words, within each industry opposites seem to att ract. Parents of affillates in "Other Europe" and the Developing Countries were not only high-wage companies in their industries but also the most

\section{6}

This is not the only possible explanation for the figures. We would get the same relationship if small U.S. firms invested only in Canada and large ones, say, only in Sweden, but that does not seem to be very likely. 


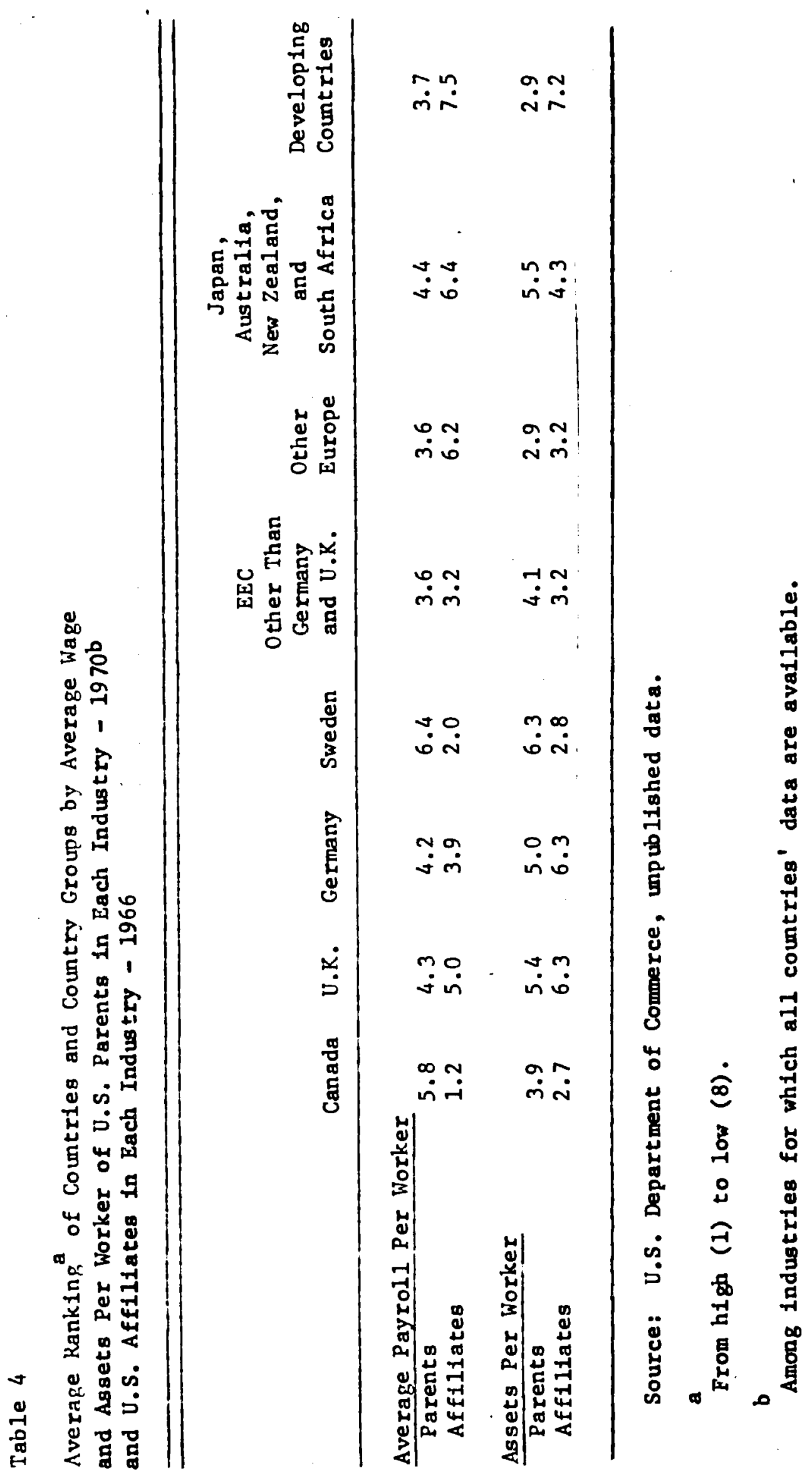


capital intensive. The companies that located in Sweden, a high-wage country, tended to be the least capital intensive in their industries.

Thus as far as factor prices and factor proportions are concerned, within Industries U.S.-parent companies do not seem to have sought cond1tions similar to those they operated under In the Unfted States. The U.S. parents drawn to each area seem to have been at the opposite end of the scale from what we would expect of local firms in that area.

If parents were Investing in locations that had attributes unlike the parents' own, 1t would not seem likely that affiliate characteristics within Industries would reflect those of their parents. We might expect that the affillates' attributes would Instead reflect those of their own locations. The second line of each set in Table 4 describes these country or country-group differences in afflliates. For example, average payroll per worker tended to be highest In Canada, and next in Sweden, followed by the EEC countries, the U.K., Other Europe, Japan, Australla, New Zealand, and South Africa, and finally the developing countries. Capital intensity was highest among affiliates in Canada, followed by those in Sweden and "Other EEC countries" and lowest in the developing countries. This is at least roughly the order we would expect from the ranking in terms of payroll per employee if that measure reflected the cost of labor rather than average skill levels. Thus the capital intensities of affiliates seem to reflect local wage costs rather than parent capital intensities within Industries.

A more systematic way of comparing parent and affiliate characterist1cs, where both are avallable, is by correlating parent characteristics with affillate characteristics. For example, a parent characteristic for 
the U.K. food Industry would be the average capital/labor ratio of U.S. parents with food industry affiliates in the U.K., relative to the average capital/labor ratio of all U.S. parents with food industry affiliates. The corresponding affiliate characteristic would be the average capital/ labor ratio of U.S. -owned food Industry affiliates in the U.K. relative to the average for all U.S.-owned food industry affillates. If we correlate affiliate and parent capital intensities in this way we find almost no relationship. That is, countries in which relatively capitalintensive parents within each industry have invested do not have relatively capital-intensive affiliates. There is thus no indication that parents are transitting technologies that can be characterized by their own capital intensities.

If we correlate payroll per worker of parents with that in affillates we do find a significant negative relation. Countries in which affiliates pay relatively high wages for their industries (as compared with other U.S. affiliates) have drawn their investment from companies paying relatively low wages in the United States $(r=-.34)$. These high affiliate wages are associated with high affiliate capital intensities within industries $(r=.42)$, as we would expect. 7 Furthermore, high parent payrolls per worker in the United States appear to be associated with low affiliate capital intensities, rather than high ones.

7 (1978).

For stronger evidence on this point see Lipsey, Kravis, and Roldan 
To summarize our findings with respect to firm characteristics within Industries, there seem to be large differences in average size between U.S. Investors in Canada and those in the less common destinations for U.S. capital, not because large U.S. firms do not Invest in Canada but because small U.S. firms invest only In Canada or first in Canada, and there is a falrly regular ordering of investment locations. Within each industry, the low-wage firms tend to have investments in high-wage countries, such as Canada and Sweden, while high-wage U.S. companies invest more frequently In low-wage destinations, such as the developing countrles. These high-wage companies are also relatively capital intensive and yet tend to be the main investors in areas in which affiliates have low capital intensities for their industries. These are not strong relationships but at least it does seem evident that there is no positive correlation, within industries, between the wage levels (and presumably the average sk111 levels) of parents or their capital intensities, and those of the countries in which they choose to locate their foreign production. If there is any relationship it appears to be that parent firms look for country characteristics that complement their own rather than resemble them.

If these differences between parent and affillate characteristics represent differences in product lines between them they fit with an earlier finding that production by U.S. firms in a host country does not substitute for U.S. exports or parent exports to that country but does substitute for exports by other countries to that host country (Lipsey and We1s8, $1976 \mathrm{a}$ and $1976 \mathrm{~b})$. A possible Inference is that the U.S. firm may be producing abroad what it was not Iikely to export from the United states In any case. 
Country Characteristics and the Location of Production for Export

The issue we are concerned with here is what country characteristice, part of the set "external" to the firm in our earlier discussion, determine location decisions by U.S. parent firms. One part of our study was a theoretical analysis of these choices (Weinblatt, 1980), based on a model of a firm minimizing the cost of serving a forelgn market or markets or the cost of serving both home and foreign markets, taking demand in each market as exogenous. That analysis pointed to, as the variables to be considered, relative costs of factors (such as labor cost) and materials, interacting with factor proportions (such as capital intensity), transfer costs (such as tariffs and freight rates), and economies of scale, both by themselves and interacting with the other variables.

Partly because we do not have worldwide measures of transfer costs, and partly to reduce the influence of subsidies and other factors for which we have no empirical measures, we have concentrated on the location of production for export rather than total production. A focus on export sourcing, rather than on manufacturing activity, has the advantage that the role of local demand in each individual host country can be expected to play a lesser and different role. Obviously a large local market makes it more worthwhile to meet the entry costs and once an affiliate is established a larger market may afford economics of scale that are conducive to exporting. Nevertheless, the influence of local demand operates on production for export only insofar as there are effects on cost via economies of scale, and that is how we will interpret demand variables. Because the factors affecting the choice between U.S. and 
foreign locations in general may be different in kind and degree from those affecting choices between alternative foreign locations, we exclude the United States as a source of exports. Thus the question which we wish to ask is how far the shares of different host countries in the worldwide exports of U.S. multinational firms (excluding the U.S. as a source) can be explained by country (rather than industry or firm) influences on relative costs of production.

Ideally, we would like to have data on the major components of costs-labor, capital, and raw material inputs--and also tax data--for each U.S. affiliate in each host country. We have had to make do with materials that fall far short of this ideal. We must also assume that the cost and productivity relationships we observe in 1966, the reference date for the Department of Commerce data we used, are similar to those which were anticipated when the investment decisions leading to the 1966 production capacity of the affiliates were made. This is unavoidable and there is but small comfort in the observation that the decisions about export sourcing may be a little easier to alter once capacity is avallable in different host countries than decisions about the location of production facilities. But against this has to be placed the practice of host countries in bargaining entry rights and capital concessions for export commitments. Although such practices were not as extensive in the 1960 's as they have become since they may still obscure the influence of the independent variables whose effect on export shares we will try to measure. 
The Data

The basic data on exports by U.S. multinationals from their majority owned manufacturing affiliates in 49 host countries consisted of the company returns to the 1966 census of direct investment abroad by the Bureau of Economic Analysis (BEA) of the U.S. Department of Commerce. 8 The 49 host countries were those included in the census for which we were able to assemble extemal country data on wages, productivity, etc. Since we did not have direct access to the census data because of the confidentiality problem, BEA kindly performed the computations for us, adding our external variables representing the cost and related characteristics of the host countries. Data for 9 major (roughly 2-digit) manufacturing and 11 subindustries were available in sufficient quantity to make analyses feasible. It was impossible to include complete coverage of manufacturing since the number of parents and affiliates in some industries was insufficient for separate regressions. Only parents reporting manufacturing affiliates in at least three host countries were included. This was done to avoid the possibility that small multinationals with affiliates in only one or two countries would, as a result of the very high shares of those host countries, dominate the results. 9 The number of host countries included in the regressions for individual industries varied from 22 to 43.

\section{8}

Some preliminary work was done on data from the 1970 survey, but the larger number of observations made the 1966 data more useful for regression analysis for individual industries.

\section{9}

Only manufacturing affiliates which met the following criteria were included in the analysis: (1) sales at least $\$ 100,000$; (2) total assets at least $\$ 100,000 ;$ (3) at least 20 employees; (4) total net sales (total sales ex sales taxes and returns) at least equal to export sales; (5) net sales at least equal to imports from the United States; (6) value added greater than zero; and (7) gross receipts at least equal to net sales. 
The dependent variable for each industry was the consolidated gross export share (CES) of each host country in the worldwide (except U.S.) exports of U.S. majority owned manufacturing affiliates. That is, the exports of U.S. parents' affiliates in each industry in each host country were summed and taken as a ratio of the world exports of all affillates of all U.S. parents in that industry. Other formulations of the export share variable are possible and some were tried in the experimental work. In one version 1 t was based on net exports. These were calculated by deducting from each affiliate's exports an estimate of the contribution to those exports of the affiliate's Imports from the United States. The purpose of this calculation was to approach more closely to a measure of production in the host country. The method was to assume that imports from the United States contributed to the affiliate's exports in the proportion they bore to the affillate's total sales. Another variant treated each parent as a separate entity for purposes of computing export shares. Neither of the alternative formulations produced substantially different results in regressions from those produced by the consolidated gross export share. The latter was in any case to be preferred marginally, at least, over the others; a consolidated rather than individual parent share better matched the countrywide cost characteristics assembled to go with the census data. Also, with respect to the net share variant, the shift from gross to net could only be accomplished very crudely. 


\section{Labor cost}

Labor cost is, of course, the most important element of cost; the compensation of employees accounted for 64 per cent of costs other than

taxes for U.S. foreign manufacturing affillates in $1966 .^{10}$ In the absence of data on the quantities of output and exports of specific types of goods and the associated expenditure on labor, we estimated labor cost per unit of output by dividing wages per worker, in dollars, by output per worker (productivity).

$$
\text { Unit labor cost }=\frac{\text { Compensation }}{\text { Output }} \sim \frac{\text { Wage per worker }}{\text { Output per worker }}
$$

Wage per worker. Preliminary regressions indicated that the shares of exports originating in different host countries tended to be positively correlated with average wages (average payroll per employee). Unless we were willing to accept the idea that a high price of labor was an attraction for an export site, the implication was that our wage per man was mainly measuring labor quality, and that exports tend to originate in countries with high quality labor, $1 . e .$, in countries with high investment per capita in human capital. To measure the impact of differences in the prices for given qualities of labor on export sourcing, we adjusted observed wages for the quality of labor. Several different ways of measuring the price of labor are concelvable. Ideally we would know the prices in different countries for labor of different types: unskilled labor, skilled labor, and probably some breakdown by type of skill. We could then introduce information on the productivity of each type of labor,

10 U.S. Department of Commerce (1976), p. 164. 
by industry, in each country or use such information to calculate unit labor costs facing an industry in each country.

In the absence of such information we tried two approximations. Both involved dividing measures of labor cost for what were thought to be roughly equivalent types of labor by the same set of country measures of output per unit of labor input, to get a measure of unit labor cost. The labor input was taken as the number of workers multiplied by the average quality of labor in the coutry, derived from data on the education level of the labor force, described below.

The labor price numerators were as follows. The first was the average payroll per worker in the particular industry, under the assumption that a given industry hired the same quality of workers in each country. The second was the average payroll per worker in all manufacturing affiliates divided by the index of the average quality of labor in the country. The assumption here was that the country differences in quality of labor in manufacturing affiliates as a group were proportional to country differences in the quality of the labor force as a whole. In this second calculation, which is the one used in Table 5, the same quality of labor measure appears in both the numerator and the denominator and therefore drops out of the measure, which reduces to average payroll per worker divided by average output per worker, or labor cost per unit of output. The equations using the two different labor cost measures were too similar to warrant showing both.

The quality of labor. There are several sources of error in using years of education as a measure of the quality of labor. In the first place, the human input into the educational process may vary in quality from one country to another and from one perfod to another within the 
same country. (For example, in a country where only a few people recelve higher education, the average quality of the students may be very high.) A second factor is that the amount learned during each year of schooling varies from country to country. Such differences, whether due to differences in the efficiency of the educational system or to factors external to the educational system, mean that years of education do not provide a satisfactory yardstick for calibrating the quality of members of the labor force in different countries. Th1rd, the relationship between educational attainment and productivity is unknown.

Finally, and perhaps the most serlous problem, our quality measure refers to the average of a country's labor force. The average qualities for all workers may differ more among countrles than the average qualities for manufacturing workers or particularly for manufacturing workers employed by multinational firms. If that is the case, we may be overcorrecting wage differences.

Despite these doubts, however, we declded to regard years of education as faute de mleux the key to labor force quality, and our problem was to find a means to convert different levels of education into differences in labor quality as reflected in differences in wage levels. Edward Denison (1967, p. 44) provided links between years of education and Income (wage) levels in the form of an Index of earnings differentials for otherwise similar Individuals who have completed 9 different levels of 5 chooling. 11

\section{1}

The Indexes are based on the welghted average 1959 earnings differentials of males at the different educational levels in each of 32 cells in a cross-classiftcation by age, region, race, and faxm vs. nonfarm occupacton. Dentson's values for each of the 9 levels of education (expressed in years of schooling) were applied to data on the average years of schooling 
A quality-adjusted average wage for each host country was then obtalned by dividing the unadjusted average wage by the Denison Index for that country.

When export shares were correlated with this revised average wage, the coefficlent of the new variable was still positive but the positive assoclation was notably weaker. ${ }^{12}$ This result could reflect reality: that 18, multinationals tend to locate production where wages are high even when corrected for quality. One would expect in this case that high wages would be associated with high productivity and thus betoken low labor cost.

Productivity. Productivity, the other term required to form the approximation of labor cost, is defined here as real GDP divided by the quality-adjusted labor force. The GDP figures are taken from the extrapolation of the data of the UN International Comparison Project, 13 and the labor force data represent the percentage of the population that

(Fn. 11 cont.)

of the economically active population in different countries to derive an index of the quality of labor. (Data on average schooling for 20 countries may be found in OECD (1971).) For countries for which average years of schooling were not avallable, interpolations were made with the aid of an earlier index of human resource quality prepared by Harbison and Myers (1964). An Index based on an assoclation between education and income established by Krueger (1968) was also used in experimental regressions, but the Denison Index performed marginally better.

\section{2}

The $\vec{r}^{2}$ were lower for 16 out of the 20 industrial classifications. Also the coefficient of the uncorrected variable was twice its standard error or more in 12 of the 20 while the same was true only in 5 cases for the corrected variable.

13

Kravis, Heston, Summers (1978b). 
was economically active as reported in the ILO Yearbook of Labor Statistics. The quality adfustment was achieved by multiplying the labor force figures by the Denison Index. 14

When export shares were correlated with labor costs, formed by the ratio of quality-adjusted wages to productivity, the coefficient of labor cost was negative in all but 2 of the 20 industrial classifications (grain mill and bakery products and primary and fabricated metals). The explanatory power of the variable was weak, however. None of the coefficients was statistically significant at the 5 per cent level and only half were larger than their standard errors.

14

This measure of productivity may serve its purpose in aiding in the calibration of labor costs, but it would be inadequate as a measure of productivity per se. For such a purpose what is needed is a measure of output per unit of output with the inputs standardized so that they not only remain constant in quality from country to country but also in proportions. That is, if the prices of all the inputs in different countries could be adjusted to refer to inputs of a standardized quality, we would not want the productivity measure to be affected by differences in the relative amount of capital or of natural resources. A pure productivity measure would therefore be a residual measure of productivity differences that cannot be accounted for by differences in the quality and quantity of resource input. Presumably the remaining differences would have their origin in general factors such as the general efficiency of the population and its work habits. Some experiments with this kind of productivity measure were attempted but they were not fruitful. 
Other Explanatory Variables

Cost of capital. International differences in the cost of physical capital are likely to be smaller than differences in the cost of a given quality of labor. In the first place, differences in the financial cost of capital to a multinational firm with affiliates in various host countries will be reduced if not eliminated by the opportunity of the parent to obtain marginal funds in the cheapest market. Secondly, with respect to the prices of physical capital, there is evidence that for the twothirds of property, plant, and equipment investment by U.S. manufacturing affiliates that consists of equipment, or producers' durables, prices tend to be very simflar in different countries. 15 The prices of construction, which accounts for the balance of gross domestic capital formation, do vary substantially among countries, tending to rise with per capita GDP. 16 The results reported upon below do not include a variable for capital costs chiefly because the only way to form a variable for such cost was from an estimating equation relating the prices of capital goods to the level of real or nominal GDP per capita. Since this was the method used to help form the productivity varlable, considerable multicollinearity was unavoidable when both the prices of capital goods

\section{5}

For the data on prices, see Kravis, Heston, and Summers (1978a), p. 120. The proportion of investment which consists of equipment is from an unpublished tabulation of the 1966 forelgn investment survey by the U.S. Department of Commerce.

16 $\operatorname{lnC}=\frac{.2928}{(5.1)} \operatorname{ln~GDP} \mathrm{EX}_{(2.1)}^{.2556}$

$$
\begin{aligned}
& \overline{\mathrm{R}}^{2}=.62 \\
& \mathrm{SEE}=.2817 \\
& \mathrm{n}=16 \\
& \overline{\ln \mathrm{C}}=.7626
\end{aligned}
$$

where $C=$ construction price index $(U S=100)$ and $G_{E X}$ is the per capita GDP converted to dollars via exchange rates and expressed as a per cent of the United States ( $t$ ratios in parentheses). 
and labor costs were included. In view of the greater importance of labor cost and the relatively small impact that differences in construction costs would have on current production costi, the results are presented in terms of labor costs alone. It may, however, be of Interest to report that in some experimental regressions with 1970 survey data the coefficient for relative construction costs had the anticipated negative sign in 8 out of 11 (approximately 2-digit) industries. 17

Cost of material inputs. A proper comparison of the relative prices of material inputs for each industry was far beyond the scope of our resources. The proxy variables we used were based on the hypothesis that the prices of raw and semi-finished materials will be lower the easier is access to world markets; that is, these prices, it is assumed, will be inversely correlated with the degree of "openness" of the host countries. The simplest measure of openness used was the $1970 \mathrm{sum}$ of exports and imports divided by GDP (OP). 18 However, OP falls to take account of the tendency for the relative importance of external trade to be inversely correlated with the size of the internal market (Kuznets, 1964). OP might indicate the same degree of openness, for example, for a small country with very restrictive trade policies (and hence high materials prices) and a large country with no restrictions (and hence low materials prices).

17

In 3 cases the coefficient was more than twice its standard error and in 1 it was 1.6 times. Coefficients for relative wages were negative in 9 of the industries including 7 of those with negative construction cost coefficients.

\section{8}

Data for GDP, exports, and imports from International Financial Statistics, except for Hong Kong and Liberia which are from U.N. Statistical Yearbook, 1973. 
To capture the effect of trade pollcies on materials prices, OP was regressed against population and population density and the residuals (ROP) taken as indicators of the ease of access in each host country to world markets for material inputs. In simple correlations between export shares and ROP the coefficient of ROP was usually significant at the 5 per cent level.

other varlables. Total GDP, converted to U.S. dollars via exchange rates, was included as a measure of the size of the host country market. The significance of this variable in the present context is mainly as an indicator of economies of scale. To the extent that econonies of scale play no role, the size of the host country market should have no influence on the sourcing of exports. Furthermore, since the economies of scale are not unlimited, their impact on export shares should be observable for a certain range of rising GDP after which the further pull of a large GDP upon location for export should diminish. These expectations are consistently fulfilled in regressions in which GDP and the square of GDP are taken as independent variables.

Experiments with several versions of tax variables, none of them very satisfactory on a priori grounds, did not prove successful and they are not reported upon here. 19

19

The tax versions used were (a) "effective income tax rates," the ratio of taxes at all governmental levels to net income before taxes, (b) "realized corporate tax rates," the definition of pretax earnings and profits as reported for U.S. tax purposes, and (c) the ratio of taxes to reported income for individual firms. The first of these tax series was obtained from the Survey of Current Business, May 1974, Part I (p. 36); the second from Hufbauer and Foster (1976), pp. 27-29, and the third set of figures from the census forms. 
Results of Multivariate Regressions

In Table 5 regressions are presented in which the consolidated export share is the dependent variable and the independent variables are those that were winnowed out in the previous discussion: labor cost, ${ }^{20} \mathrm{GDP}$, $\mathrm{GDP}^{2}$, and the Residual Openness variable (ROP). The complete set of anticipated signs $(-+-+)$ is found in 14 of the 20 equations with $\bar{R}^{2}$ ranging . 30 to .55 in 9 of these industrial classifications. The coefficients of GDP and ROP have the expected signs in all the equations and are usually (14 out of 20) significant at the 5 per cent level. The success of ROP raises the question of whether it is serving, as intended, only as a price indicator for material inputs. Perhaps it reflects the host country's general propensity to trade; if so, the convenience of los: cost trading facilities (transport, finance, etc.) may be the elements that are really influencing the export behavior of multinationals. The coefficient of the squared term for GDP is negative with but one exceptim, though it is less often statistically significant ( 7 out of 20 at the 5 per cent leve1).

The labor cost variable is the major disappointment, being the weakest in contributing to the explanation of export shares. While its coefficlent is generally (15 out of 20) negative, it falls to reach the 5 per cent significance level in any of the classifications and is

20

Our measure of labor cost is

$$
\frac{\text { Average wage, all affiliates/Denis on Index }}{\text { Real GDP per capita/National labor force } x \text { Denis on Index }}
$$

which equals the total wage bill (based on the affiliates' average wage) per unft of real GDP. The alternative varlant of labor cost based on the average wage of affiliates in the given industry in the host country (without further correction for quality of labor) ylelded simflar though marginally inferior results. In the version used in Table 6 the Denis on Index cance is out, but in the alternative version it remains in the denominator of the productivity index. 
TARLE 5

Explanation of Export Shares in Terms of Labor Cost, Total Real COP, and Opennes:"

Food

\begin{tabular}{ccccc}
\multicolumn{5}{c}{ Independent Variables } \\
\hline Labor & Total & Square of & Residual \\
Cost & Real GDP & Total Real & Openness & $\vec{F}^{2}$
\end{tabular}

(1)

(2)

(3)

(4)

(s)

$\begin{array}{ccccc}-19.39 & 7.37 & & & \\ (.73) & (2.23) & -.280 & .033 & .213 \\ & & (2.11) & (2.02) & (3.43)\end{array}$

Gain, Mill, Bakery

168.41

6.08

$-.227$

(1.61)

(.77)

(.80)

$(3-66)$

$-366$

Beverages

34.92

16.5

$-.508$

$-117$

(4.32)

other Food

(.40)

(2.29)

(1.88)

(2.97)

.398

$-26.20$

6.85

(.89)

(1.88)

$-.269$

(1.85)

$-018$

(4.46)

Cherical

$-18.98$

10.6

(.81)

(3.45)

$-.329$

(2.66)

(-99)

.084

Drugs

$-32.12$

10.0

(.91)

(2.36)

$-.309$

$-37.76$

10.4

(.96)

(2.16)

(1.79)

$-040$

(3.07)

Soap. Cosmetics

$-.22$

8.95

Otber Cbenical

(.01)

(2.59)

$-.311$

(1.61)

.019

(.99)

Rikies, Plastle

$-27.73$

4.53
8.69

$-.279$

(2.03)

.024

(1.17)

$\because \cdot$

(.76)

.053

(-16)

.089

(4.65)

(2.52)

retals

61.54

12.5

(1. 30)

(2.08)

(1.51)

.047

(2.17)

$-523$

Kon-Electrical Machinery

$-53.30$

(1.12)

14.2

(3.18)

$-.363$

(2.07)

.050

$\left(\begin{array}{c}-050 \\ (1.77)\end{array}\right.$

$-73.62$

Coputers, Office Kach.

(.98)

17.2

$\cdot(2.87)$

. .414

(1.83)

.039

(1.85)

(6.19)

Other Eon-electrical

$-53.56$

13.8

(.98)

(2.69)

$-.387$

(1. 92$)$

$-032$

(1.10)

.398

$-24.42$

12.6 .

(.91)

(3.64)

$-.344$

Electrical Machinery

Radio, IV

$-67.30$

(1.06)

10.7

(2.45)

(2.48)

.053

(2.16)

(4.47)

Oener Electrical Maci.

$-11.26$

(.33)

16.5

(3.69)

(2.68)

.041

(2.61)

(4.38)

Transportation Equipsent

51.07

$13: 0$

(.60)

(1.73)

$-.342$

(1.21)

.052

(8.0́3)

potor vehicles

40.43

13.1

(.48)

(1.76)

$-.334$

(1.19)

(2.18)

.381

-50.47
$(.59)$

9.17

$-.310$

(1.34)

(1.17)

.055

(2.67)

$-426$

(6.75)

stone, Clay, Glass

$-15.17$

15.5

(.25)

(3.09)

$-.406$

(2.15)

.137

.417

(4.75)

(3.36)

$\$ 003$

Instruments.

- Constant term not reported. Dependent varlable: consolidated export share. For deflnition of this ais of independent varlabies, see text. (t ratlos in parentheses). 
larger than its standard error only in two of the cases in which it has a negative sign. This may be due to the deficiencies of the measure-particularly our possible failure to adjust correctly for quality differences, and the use of a labor cost measure that is the average for all affiliates in a given host country. It mav be that firms are concerned with costs of specific types of labor and that these vary among countries in ways very different from the average labor cost. For example, skilled labor might be cheap in Sweden and expensive in Latin America, while average labor costs are high in Sweden and low in Latin America. We are also unable to include some of the most labor-intensive industries, such as clothing and textiles, because there was not enough U.S. investment to permit us to run equations.

The individual industries may be classified by size of the $\bar{R}^{2}$ and by degree of conformance to expected signs:21

Wrong Sign for One Variable ${ }^{22}$

Comple te Conformers

Industries with $\overline{\mathrm{R}}^{2}<.30$

$\overline{\mathrm{R}}^{2}$ $\bar{R}^{2}$

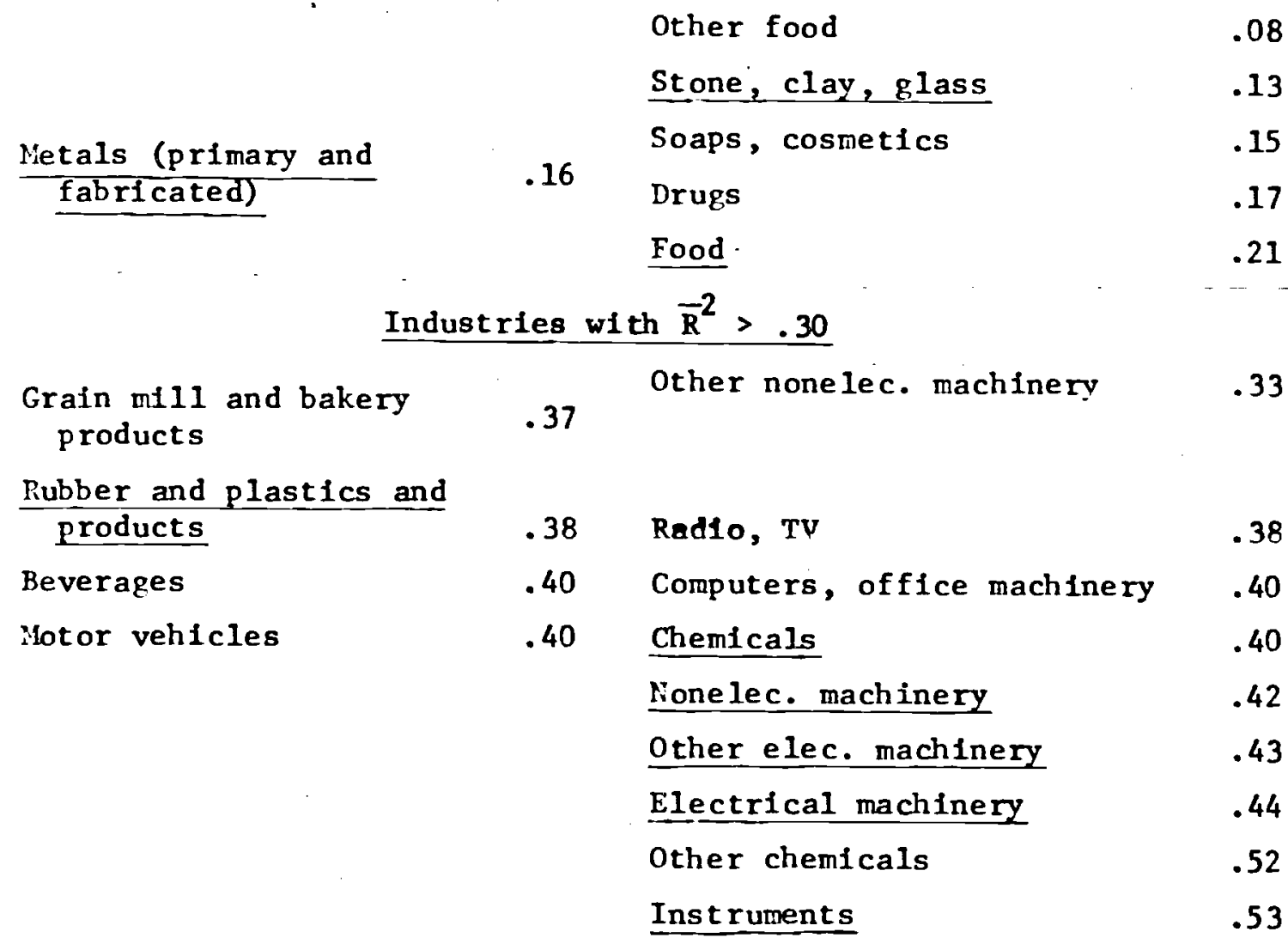

21

Najor industries underlined.

22

Coefficient of labor cost had wrong sign except for Rubber and plastics and products, for which the coefficient of $\mathrm{GDP}^{2}$ had the wrong sign. 
The nonconformities were positive coefficients for labor cost except for rubber and plastics and products which had a positive sign for GDP ${ }^{2}$. Perhaps this industry more than others needs a very large market. When this variable is deleted the resulting equation conforms with respect to the remaining variables $\left(\vec{R}^{2}=.41\right)$.

It is not easy to explain the patterns which lead to the distribution of the industries among the 4 classes. Primary and fabricated metals may be pulled to locations rich in mineral resources or with cheap energy, factors which are not included among the explanatory variables. A simflar point regarding resource orientation may apply to stone, clay and glass. For the rest, perhaps the most striking difference is the predominance of Industries catering to consumer markets in the low $\overline{\mathrm{R}}^{2}$ group. Industries selling capital goods or other inputs for other Industries tend to fall more uniformly in the high $\bar{R}^{2}$ category and also to conform completely to the mode1. Indeed, with the exception of transportation equipment and motor vehicles, for both of which sales of automobiles to consumers loom very large, all the capital goods industries are found in the conforming category with high $\overline{\mathrm{R}}^{2}$. Again, it is the regularity with which negative labor cost coefficients appear that is notable since no individual one is statistically significant.

It was thought that the pattern might reflect different labor and capital intensities of the industries. Labor-intensive industries might, for example, be more attracted to low labor cost countries. However, an effort to link the results to variations in capital/labor intensities of the industries did not succeed. ${ }^{23}$

\section{3}

When the ratio of payroll to value added was taken as the measure of relative factor intensity no consistent associations were found with the three sets of Industries. (Data from Bureau of the Census, Census of Manufactures, 1967, Vol. 1). Then net capital stock per dollar of payroll 
A problem that hangs over these regressions is the fact discussed earlier that, regardless of Industry, there seems to be a country pattern of investment that puts Canada first, followed by the U.R. and Mexico, and then Germany and France. It is clear that there are influences at work outside the range of the variables included in our export sourcing regressions. These influences, which might concelvably affect export sourcing less than they affect production for host-country consumption, might include both proximity to the United States and language. One way to introduce such influences is to include dumny variables for a few countries or for sets of countries. The disadvantage of this procedure is that such dummy variables are correlated with some of the economic variables and thus tend to blur their effects. For example, Canada was the highest-wage foreign country.

We did experiment with country dumies for Canada, the U.K. and EEC (Six) countries in some earlier versions of these equations, and some of the results were startling. In equations including such dummies

(Fn. 23 cont.)

for 9 major industries was used to measure factor intensity, the industries producing capital goods (all in our third category, except transportation equipment) had low capital intensities. However, the chemical industry, also in our third category, had the highest capital/labor ratio of all 9 . Payrolls from 1dem: 1967 net capttal stock from U.S. Bureau of Labor Statistics, Capital Stock Estimates for Input-Output Industries: Methods and Data, Bulletin 2034, 1979). The effort to link the Influence of labor cost on export source decisions to the factor intensities of different industries may have falled because the factor intensity measures reflect the mix of subindustries in each major industry in the United States and these may have been very different from the $\mathrm{mix}$ among U.S. affiliates abroad. For example, in the U.S. motor vehicles accounted for only 40 per cent of the payroll and 60 per cent of the net capital stock of the broader industry, whereas motor vehicle payrolls and capital stock probably accounted for much higher percentages in U.S. transportation equipment abroad. In the comparisons reported upon in the text we took the net capital stock per dollar of payroll in the transportation industry of $\$ .87$, though 1t might have been more appropriate to use the $\$ 1.32$ of the motor vehicle component. In the other major industries it was not so obvious what adjustments should be made. 
as well as wage rates, productivity, GDP, and $R O P$ as independent variables, the $\overline{\mathrm{R}}^{2}$ ranged from .42 to .94 compared to a range of .06 to .52 without the country dumies. However, the high $\vec{R}^{-2}$ achieved by using dumny variables are hard to interpret, since they mix together the economic and "non-economic" factors. The "non-economic" factors may be mislabeled. Proximity and Identity of language may both be major cost-reducing influences. Furthermore, inclusion of the dummy variables often destroys the significance of the other variables. For example, the coefficients for ROP are almost eliminated by the introduction of dummies for all three areas. One may take the view that the ROP variable is simply a proxy for a few countries or alternatively that the dummy variables serve as proxies for the ROP as well as other characteristics. However, it seems preferable to favor specific variables that account for the strong effects of the dumny variables in these equations. That is the strategy reflected in Table 5 . Another way of searching for missing country influences is to examine the residuals from the equations of Table 5. These give some very different impressions from the earlier discussion. The clearest outlier, with a large positive residual, is the U.K.: the equations consistently underestimated U.S. fIrms' exports from there. The only other large average positive residual was for Canada and we also tended to underestimate exports from Denmark, Austria, Chile, Colombia, and Peru. We consistently overestimated U.S. firms' exports from Italy, Spain, Australia, India, Malaysia, Brazil, and Venezuela. Thus several of the countries high on the list of production locations, such as Australia, Mexico, France, and Germany, do not rank exceptionally high, once we take account of the variables included in the equations, as locations for export production. 
The results of this work on the location of production for export provide strong indications that U.S. majority-owned affiliates tended to export from countries with:

1. large internal markets. However, after a certain point had been reached, the influence of market size seemed to taper off, and to produce smaller further increases in the host country's share of world exports. Since there is no logical direct link between large markets in a country and exports from that country we interpret that finding as having several implications. First, proximity to markets is a major factor in selecting locations for production. Second, that in these industries there were economies of scale in production that made output cheaper to produce in large markets. Third, within the range of market sizes we observed, economies of scale began to decline with the result that the peak rate of increase in the share of exports came at a market size below the largest.

2. high propensities to trade. Whether this was due to better access to imported material inputs at low world prices or to better transport, finance, and other facilities for trade is not clear. Another possibility, at least for small countries, is that the presence of U.S. affiliates contributed to the high trade ratios.

With respect to wages, there was only slight evidence for a negative association between export shares and labor cost, at least as crudely as the latter is measured here. Noreover, this evidence is not found in any 
single Industry equation, but rests only on the predominance of negative signs for the labor cost coefficlent in the 20 countries. U.S. majorityowned affillates tended to export from countries with high wages, but the high productivity of such countries tended to offeet the high wages fully or even a little more than fully. Clearly, labor cost was not a major influence in the location of export production Insofar as we have been able to measure it correctly.

This Investigation of the factors influencing the location of production by multinationals reveals underlying oystematic elements in locational decisions, and thus offers support for the hypothesis that the multinationals tend, at least to some degree, to be market scanners. The cholces made by parent firms among different locations for their affiliates follow an "opposites attract" tendency: Within given Industries, low-wage, low-capital-intensity parents tend to place affillates in high-wage, high-capital-intensity countries and vice versa for high-wage, high-capitalIntensity parents.

The extent to which cost factors determine the 10cation of export production varles, it seems, from industry to industry. Industries producing capital equipment (and the parts of the chemical industry that sell to industrial customers) seem to fit the market scanning hypothesis better than Indus tries producing goods that are purchased, with little further transformation, by consumers. Perhaps industrial buyers are more expert and the competition for their business causes producers to welght cost factors more heavily In locating their production for export, while consumers may be more Influenced by marketing strategles that entall less competitive price pressures for producers. 
List of References

Denis on, Edward F. (1967), Why Growth Rates Differ, Brookings Institution,
Washingtion, D.C.

Dunning, John H. (1977), "Trade, Location of Economic Activity, and the MNE: A Search for an Eclectic Approach," in The International Allocation of Economic Activity, Proceedings of a Nobel Symosi um held at Stockholm, Edited by Bertil Ohlin, Per-Ove Hesselborn, and Per Magnus Wijkman, Holmes and Meler, New York.

Horst, Thomas (1972), "Firm and Industry Determinants of the Decision to Invest Abroad: An Empirical Study," Review of Economics and Statistics, August.

Harbison, Frederick and C.A. Myers (1964), Education, Manpower, and Economic Growth, McGraw-H111, New York.

Hufbauer, Gary and D. Foster (1976), "U.S. Taxation of the Undistributed Income of Controlled Foreign Corporations," in U.S. Department of the Treasury, Essays in International Taxation, Tax Policy Research Study No. 3, washington, D.C.

Kravis, Irving B., Alan Heston, and Robert Summers (1978a), United Nations International Comparison Project: Phase II: International Comparisons of Real Product and Purchasing Power, Johns Hopkins University Press, Baltimore and London.

(1978b), "Real GDP Per Capita for More Than One Hundred Countries," Economic Journa1, June.

Kuznets, Simon (1964), "Quantitative Aspects of the Economic Growth of Nations: Level and Structure of Foreign Trade, IX. Comparisons for Recent Years," Economic Development and Cultural Change, Vo1. 13,
No. 1, October.

Krueger, Anne 0. (1968), "Fact or Endowment and Per Capita Income Differences Among Countries," Economic Journal, September.

Lipsey, Robert E., Irving B. Kravis, and Romualdo A. Roldan (1978), "Do Multinational Firms Adapt Factor Proportions to Relative Factor Prices?," NBER Working Paper 293. To be published in Altemative Trade Strategies and Employment: Supply Response and Factor Market Links, Edited by Anne 0 . Krueger, University of Chicago Press.

Lipsey, Robert E. and Merle Yahr Weiss (1976a), "Exports and Foreign Investment in the Pharmaceutical Industry," NBER Working Paper 87 (Revised), January.

(1976b), "Exports and Forelgn Investment in Manufacturing Industries," NBER Working Paper 131 (Revised), May. 
Organization for Economic Cooperation and Development (1971), Occupational and Educational Structures of the Labor Force and Levels of Economic Development, Paris.

Richardson, J. David (1971), "On Going Abroad: The Firm's Initial Foreign Investment Decision," Quarterly Review of Economics and Business, Vol. 11, Winter.

Samuelss on, Hands-Fredrik (1977), Ut ländska Direkta Investeringar 1 Sverige, Industriens Utredningsinstitut, Stockholm.

Swedenborg, Birgitta (1979), The Multinational Operations of Swedish Firms: An Analysis of Determinants and Effects. The Industrial Institute for Economic and Social Research (Industriens Ut redningsinstitut), Stockholm.

Taubman, Paul and Terence Wales (1972), "Mental Ability and Higher Education Attainment in the Twentieth Century,"NBER Occasional Paper 118, New York.

U.S. Department of Commerce (1976), U.S. Direct Investment Abroad, 1966: Final Data, A Supplement to the Survey of Current Business, Nashingt on, Government Printing office.

Weinblatt, J. "Exports and Foreign Production by Multinational Corporations," Unpublished paper, NBER, 1980. 